\title{
Prevalence of Candida and Trichomonas in Vaginal Discharge of Rural Females not Seeking Medical Help: Microscopy and its Role in Vaginitis
}

\author{
Rachna Tewari*, Motilal P. Sah and Mridu Dudeja \\ Department of Microbiology, HIMSR, Jamia Hamdard, New Delhi, India \\ *Corresponding author
}

\author{
A B S T R A C T
}

\begin{tabular}{|l|}
\hline Ke y w o r d s \\
Candida, \\
Trichomonas, \\
Vaginal discharge. \\
\hline Article Info \\
\hline $\begin{array}{l}\text { Accepted: } \\
\text { 26 September } 2017 \\
\text { Available Online: } \\
\text { 10 October } 2017\end{array}$ \\
\hline
\end{tabular}

\section{Introduction}

Abnormal vaginal discharge with or without other symptoms, is one of the major problem in developing countries. It can be infective or non-infective.

In rural areas it has been noted that this morbidity is tolerated silently by women due to various social factors as poor awareness, gender inequalities, lack of proper education and lack of focused counselling and financial dependence. Candidiasis and Trichomoniasis are two of the most common causes of vaginal discharge $\mathrm{e}^{(1-6)}$ Candida is a yeast like fungus, normally found as the lower genital tract flora in $20-50 \%$ of healthy asymptomatic females ${ }^{(7-8)}$. Carrier rates are higher in women using broad spectrum antibiotics ${ }^{(9)}$, pregnant, diabetic women ${ }^{(10-11)}$ and women with HIV/AIDS ${ }^{(8,12,13)}$. Candida albicans is the commonest cause for most cases of vulvovaginal candidiasis (VVC) than other species of Candida. It is characterized by severe itching, burning sensation, redness and curdy white discharge ${ }^{(9,14)}$. In unattended 
pregnant females can lead to preterm labour and low birth weight. Also these females are at risk of acquiring other STDs more.

Trichomoniasis is caused by a protozoa, Trichomonas vaginalis which is a sexually transmitted parasite resulting in discomfort, frothy yellow greenish vaginal discharge, irritation, pain in vulva, perineum, dyspareunia, dysurea and psychosocial distress in the infected patients. It has also been reported to cause complication in pregnant women like post abortion infection, post caesarean infection, preterm birth, low birth weight infants and preterm labour $(15,16)$.

Asymtomatic or mild cases of Candidasis and Trichomoniasis may not be taken seriously by rural patients and may lead to severe complications like infertility or complications associated with pregnancy and make them vulnerable to other type of sexually transmitted diseases (STDs).

Keeping the above fact in view this study was carried out to see the hidden infection by organizing camps and door to door service to find out affected women who need treatment and counseling for these infections at right time so that spread and complications can be prevented.

\section{Materials and Methods}

A cross sectional study was conducted by the Department of Microbiology, HIMSR, New Delhi, in March 2017. Camps were organized in slums and rural areas. A total of 200 women with complaints of vaginal discharge were recruited. After taking consent complete history and general and gynaecological examination was carried out. Three high vaginal sterile swabs from lateral wall and posterior fornix were collected using a speculum during comprehensive pelvic examination. The nature of discharge (amount, colour, character, and smell) was evaluated. First swab is used to prepare Wet mount to see motility of Trichomonas vaginalis, fungal buds, bacteria and pus or other type of cells and to make $\mathrm{KOH}$ preparation. Second swab of each patient was used to make smears for Grams and Giemsa stain. Third swab was inoculated in normal saline and carried to microbiology lab at sterile conditions for culture. Blood Agar (BA) and Sabrauds Dextrose agar (SDA), Hi Media, Mumbai was inoculated for swabs showing budding yeast in Grams stain and $\mathrm{KOH}$ mount ${ }^{(17-18)}$.

\section{Inclusion criteria}

Females of age 18-48 years with complaint of excessive vaginal discharge.

Those who were willing for speculum examination

\section{Exclusion criteria}

Not giving consent for speculum examination.

Women who were menstruating or have attained menopause.

Bacterial and non-infective cases were excluded.

\section{Identification of organisms}

For Candida

$\mathrm{KOH}$ preparation - Little vaginal secretion was taken on clean slide and a drop $10 \%$ $\mathrm{KOH}$ was mixed and covered with cover slip. Microscopy under 10x and 40x was performed. Round and oval shaped budding yeast cell were identified as Candida.

Grams stain- Gram positive budding yeast cell were identified as Candida in Gram stained vaginal smear. 
Culture - It was done on SDA (Sabrauds Dextrose Agar) in lab. Cream coloured, smooth, moist colonies were confirmed as Candida by making their Grams Stain.

GTT - Isolated candida colonies were transferred to human sera and seen for tube like yeast cell and pseudohyphae were seen under microscope ${ }^{(18) .}$

\section{For Trichomonas vaginalis}

Wet mount: motile trophozoites were identified.

Giemsa Stain: oval trophozoites were seen (18).

Ethical clearance was obtained from the department. Eligible females were informed and counselled about the benefits and risk of studies. The consent of all patients were verbally taken before collecting sample and data. Data were analysed using MS excel and appropriate statistical methods.

\section{Results and Discussion}

In the current study of two hundred females, with complaint of vaginal discharge following observations were noted. Out of these 200 women $73(36.5 \%)$ were diagnosed to be having infective vaginitis. The prevalence of candidiasis was found in $24(12 \%)$ females out of which majority i.e. $22(90 \%)$ were confirmed as Candida albicans and $10 \%$ as other Candida species. Trichomonas vaginalis was identified in $9(4.5 \%)$ females. No case of mixed infection was found (Table 1).

Candida was found in high frequency $(52.7 \%)$ in age group 39-48 years of females. Prevalence of vaginal candidiasis and Trichomoniasis was found higher in unemployed $25(20.4 \%)$ than employed women $8(10.1 \%)$. No significant correlation was found with educational status in these areas. Lower incidence $14.8 \%$ of infection was found in not educated females where as $18 \%$ in higher qualified and $21.6 \%$ in mediocre (Table 3 ).

$24(12 \%)$ patients were identified as having infection with Candida species. By performing microscopic examination in field $75 \%$ strains can be isolated by $\mathrm{KOH}$ mount and $83.3 \%$ by Grams staining when we compared it with culture all (100\%) (Table 3). Germ tube test was found positive for $91.6 \%$ strains. Trichomonas vaginalis was identified in $9(4.5 \%)$ patients by microscopic examination by wet mount and Giemsa Stain (Table 4).

Infection in the genital tract produce serious complications and can be transmitted to others ${ }^{(19-20)}$ The doctors or health workers commonly encounter the females associated with vaginal discharge with or without itching or foul smell. Infectious vaginitis primarily caused by bacteria, yeast and protozoa account for $90 \%$ of the disease. Vulvovaginal candidiasis and trichomoniasis are the leading cause of vaginitis $^{(21-22)}$.

Mostly these studies have been conducted in hospitals in urban area. In our study we are reporting about the females who themselves have not contacted doctors but have been contacted by the health care workers to find out the hidden infection in the community which should also be prevented and treated in time to control the transmission. So this prevalence should be added to the prevalence being reported till now.

In our study we have reported $12 \%$ females having candidiasis which is higher than reported by other studies ${ }^{(23-24)}$ which may be due to their large sample size. However it was slightly less as compared to $22 \%$ reported by Venugopal et al., ${ }^{(25)}$. 
Table.1 Etiology of vaginal discharge and its prevalence

\begin{tabular}{|l|c|c|}
\hline Aetiology & Number (Total -200) & Percentage \\
\hline Candida albicans & 17 & $8.5 \%$ \\
Candida species & 07 & $3.5 \%$ \\
\hline Trichomonas vaginalis & 9 & $4.5 \%$ \\
\hline Other infection & 40 & $20 \%$ \\
\hline No organism found & 127 & $63.5 \%$ \\
\hline
\end{tabular}

Table.2 Demographic characteristics associated with infection

\begin{tabular}{|c|c|c|c|c|}
\hline Level of Education & Number $(\mathrm{N})$ & Organism & number $(\mathrm{n})$ & $\begin{array}{c}\text { (Percentage) } \\
\mathrm{n} / \mathrm{N} \times 100\end{array}$ \\
\hline Less than high school & 108 & $\begin{array}{l}\text { Candida } \\
\text { Trichomonas }\end{array}$ & $\begin{array}{c}12 \\
4\end{array}$ & $\begin{array}{c}11.1 \\
3.7\end{array}$ \\
\hline More than high school & 72 & $\begin{array}{l}\text { Candida } \\
\text { Trichomonas }\end{array}$ & $\begin{array}{l}9 \\
4\end{array}$ & $\begin{array}{c}12.5 \\
5.5\end{array}$ \\
\hline Not educated & 20 & $\begin{array}{l}\text { Candida } \\
\text { Trichomonas }\end{array}$ & $\begin{array}{l}3 \\
1\end{array}$ & $\begin{array}{l}15 \\
6.6 \\
\end{array}$ \\
\hline $\begin{array}{l}\text { Employed } \\
\text { Unemployed }\end{array}$ & $\begin{array}{c}78 \\
122\end{array}$ & $\begin{array}{l}\text { Candida } \\
\text { Trichomonas } \\
\text { Candida } \\
\text { Trichomonas }\end{array}$ & $\begin{array}{c}6 \\
2 \\
\\
18 \\
7\end{array}$ & $\begin{array}{c}7.6 \\
2.5 \\
\\
14.7 \\
5.7\end{array}$ \\
\hline $\begin{array}{l}\text { AGE in years } \\
18-28 \\
29-38\end{array}$ & $\begin{array}{l}121 \\
60\end{array}$ & $\begin{array}{l}\text { Candida } \\
\text { Trichomonas } \\
\text { Candida } \\
\text { Trichomonas } \\
\text { Candida } \\
\text { Trichomonas }\end{array}$ & $\begin{array}{c}7 \\
4 \\
\\
10 \\
2\end{array}$ & $\begin{array}{c}11.6 \\
6.6 \\
52.6 \\
10.5\end{array}$ \\
\hline Pregnant & 28 & $\begin{array}{l}\text { Candida } \\
\text { Trichomonas }\end{array}$ & $\begin{array}{l}9 \\
1\end{array}$ & $\begin{array}{c}32.1 \\
3.5\end{array}$ \\
\hline Not pregnant & 172 & $\begin{array}{l}\text { Candida } \\
\text { Trichomonas }\end{array}$ & $\begin{array}{c}15 \\
8\end{array}$ & $\begin{array}{l}8.7 \\
4.6\end{array}$ \\
\hline
\end{tabular}


Table.3 Lab result of Candida species

\begin{tabular}{|l|c|c|c|c|}
\hline $\begin{array}{l}\text { Positive } \\
\text { specimen }\end{array}$ & $\begin{array}{c}\text { KOH } \\
\text { mount18/24(75) }\end{array}$ & $\begin{array}{c}\text { Grams stain } \\
20 / 24(83.3)\end{array}$ & $\begin{array}{c}\text { Culture 24/24 } \\
(100)\end{array}$ & Germ tube 22/24 \\
\hline 12 & + & + & + & 11 \\
\hline 8 & - & + & + & 8 \\
\hline 4 & + & - & + & 3 \\
\hline
\end{tabular}

Table.4 Lab result of Trichomonas vaginalis

\begin{tabular}{|l|c|c|}
\hline Positive specimen & Wet mount7/9 & Giemsa staining 7/9 \\
\hline 5 & + & + \\
\hline 2 & - & + \\
\hline 2 & + & - \\
\hline
\end{tabular}

Table.5 Prevalence of candidiasis and Trichomonas vaginalis reported earlier and in present study

\begin{tabular}{|l|l|l|l|l|}
\hline Author & Year & $\%$ age & Place of study & Journal \\
\hline $\begin{array}{l}\text { Swetha } \\
\text { Venugopal, } \\
\text { Kannan Gopalan }\end{array}$ & 2017 & $\begin{array}{l}\text { Candida 22\% } \\
\text { Trichomonas } \\
25 \%\end{array}$ & $\begin{array}{l}\text { Salem. Tamil } \\
\text { Nadu }\end{array}$ & $\begin{array}{l}\text { Indian Journal of } \\
\text { Sexually } \\
\text { Transmitted } \\
\text { Diseases and } \\
\text { AIDS Volume 38 }\end{array}$ \\
\hline $\begin{array}{l}\text { B. Anuradha*, } \\
\begin{array}{l}\text { M.C.K. Joanna } \\
\text { and M. Praveena }\end{array}\end{array}$ & 2015 & $\begin{array}{l}\text { Trichomonas } \\
22.22 \%\end{array}$ & Khammam, India & IJCMAS \\
\hline $\begin{array}{l}\text { R Bansal, N } \\
\text { Jindal, B Chand }\end{array}$ & 2013 & $\begin{array}{l}\text { Trichomonas } \\
6.1 \%\end{array}$ & $\begin{array}{l}\text { Punjab } \\
\text { India }\end{array}$ & Ijmm \\
\hline Alli et al., $\quad 2011$ & Candida 22\% & Nigeria & JMBR \\
\hline $\begin{array}{l}\text { Madhivanan et } \\
\text { al., }\end{array}$ & 2008 & $\begin{array}{l}\text { Candida 30.8\% } \\
\text { Trichomonas } \\
8.2 \%\end{array}$ & $\begin{array}{l}\text { Mysore } \\
\text { India }\end{array}$ & IJMM \\
\hline
\end{tabular}

Trichomoniasis is a common STD found in humans. We have reported prevalence of $4.5 \%$ which is equivalent to reported by other studies. It has been found that prevalence varies from place to place and with social condition from study to study and reported to be low as $2-8 \%$. Whereas high $22-45 \%$.

This may be due to the high risk nature of group ${ }^{(25-27)}$. A very high prevalence of TV $47 \%$ was reported ${ }^{(28)}$. Studies have indicated it as reemerging pathogen and found to correlate with age.

Despite the various techniques available and found to be little more sensitive for diagnosing candida species and Trichomoniasis wet mount with clinical features still comes out as reliable screening test (Tables 4 and 5) in rural areas. Although many studies ${ }^{(29)}$ have found more positivity by culture (13.9\%) then by wet mount (11. 
4\%). Microscopy is reliable, inexpensive method, which can be done in field with no requirement of specialist.

Microscopy in the field, substantiated with sign and symptoms is easy, inexpensive and reliable methods to detect the infection in rural females not attending clinics for treatment. It is highly recommended that STDs should be prevented, diagnosed and treated early to avoid complications and reduce transmission. This study was done to create awareness in rural and slum area about health care facilities and self-concern in females for their health. Camps and door to door surveys should be performed to approach these types of unaware females.

\section{References}

1.Joshi A, Dhapola M, Pelto PJ. Gynaecological Problems: Perceptions and Treatment-seeking Behaviours of Rural Gujarati Women. In: Michael A Koenig, ShireenJejeebhoy, John C Cleland and BelaGanatra (eds.) Reproductive Health in India New Evidence. Jaipur: Rawat Publications. 2008; 133-58.

2.Bhatia, Bhatia JC, Cleland J, Bhagavan L, Rao NS. Levels and determinants of gynecological morbidity in a district of south India. Stud Fam Plann 1997; 28:95-103.

3.Gittlesohn J, Holmes KK, Pilot P, Et al (eds.) Listening to Women Talk about Their Health: Issues and Evidence from India. New Delhi: Har-Anand Publications. 1994; 21-36.

4.Oomman, N. Poverty and pathology: Comparing rural Rajasthani women's ethnomedical models with biomedical models of reproductive morbidity: Implications for women's health in India. Dissertation thesis submitted to John Hopkins University, Baltimore, USA. 1996.
5.Wasserheit JN, Harris JR, Chakraborty J, Kay BA, Mason KJ. Reproductive tract infections in a family planning population in rural Bangladesh. Stud FamPlann 1989; 20:69-80.

6.Younis N, Khattab H, Zurayk H, elMouelhy M, Amin MF, Farag AM. A community study of gynecological and related morbidities in rural Egypt. Stud FamPlann 1993; 24:175-86.

7.McClelland RS, Richardson BA, Hassan WM, Graham SM, Kiarie J, Baeten JM, Mandaliya K, Jaoko W, Ndinya-Achola JO, Holmes KK. 2009. J. Infect. Dis. 15; 199(12): 1883-1890.

8.Adad SJ, de Lima RV, Sawan ZT, Silva ML, de Souza MA, Saldanha JC, Falco VA, da Cunha AH, Murta EF. 2001. Sao Paulo Med J. 119(6):200-205.

9.Singh SI. 2003. Treatment of vulvovaginal candidiasis. Clin. Rev. CPJ/RPC. 136(9): 26-30.

10. Donders GG, (2002). Curr Infect Dis Rep. 4(6): 536-539.

11.de Leon EM, Jacober SJ, Sobel JD, Foxman B (2002). BMC Infect Dis. 2(1). doi:10.1186/1471-2334-2-1.

12.Reed BD, Zazove P, Pierson CL, Gorenflo DW, Horrocks J. 2003. J. Women's Health (Larchmt). 12(10): 979-89.

13. Duerr A, Heilig CM, Meikle SF, Cu-Uvin S, Klein RS, Rompalo A, Sobel JD, (2003). Obstet Gynecol 101(3): 548-56.

14. Mackay MD. Gynecology. In: Tierney LM, McPhee SJ, Papadakis MA, editors. Current Medical Diagnosis and Treatment. Connecticut: Appleton and Lange; 1998:691-723.

15.Graves A, Gardner WA jr. Pathogenicity of Trichomonas vaginalis. Clin ObstetGynaecol 1993; 36:145-151.

16.Nanda N, Michel R G, Kurdgelashvili G, Wendel KA. Trichomoniasis and its treatment. Expert Rev Anti Infect Ther 2006; 4(1): 125-35.

17.Cheesebrough M. 2006. District 
laboratory practice in tropical countries. Part 2.Cambridge University Press, United Kindgom; p.434

18.Bailey and Scotts Bailey, W. R., Scott, E. G., Finegold, S. M., and Baron, E. J. (1986). Bailey and Scott's Diagnostic microbiology. St. Louis, Mosby.

19 .Rajalakshmi R, Kalaivani S. Prevalence of asymptomatic infections in sexually transmitted diseases attendees diagnosed with bacterial vaginosis, vaginal candidiasis, and trichomoniasis. Indian J Sex Transm Dis 2016; 37:13942

20.Akingbade OA, Akinjinmi AA, Awoderu OB, Okerentugba PO, Okonko IO. Prevalence of Candida albicans amongst women attending health centres in Abeokuta, Ogun State, Nigeria. N Y Sci J 2013; 6: 53.

21.Fox KK, Behets FM. Vaginal discharge. How to pinpoint the cause. Postgrad Med 1995; 98: 87-90.

22.Vijaya Mn D, Umashankar K, Sudha, Nagure AG, Kavitha G. Prevalence of the Trichomonas vaginalis infection in a tertiary care hospital in rural Bangalore, Southern India. J Clin Diagn Res 2013; 7:1401-3.

23.Pawanarkar J,Chopra K. Prevalence of lower reproductive tract infection in infertile women. Health Popul Perspect Issues. 2004; 27: 75.
24.Gupta V, Chatterjee B, Prasad D. Clinical spectrum and microbial etiology of reproductive tract infections in rural women in the hills of North India. J Obst Gynaecol India 2002; 52:130-4.

25.Venugopal S, Gopalan K, Devi A, Kavitha A. Epidemiology and clinicoinvestigative study of organisms causing vaginal discharge. Indian J Sex Transm Dis 2017; 38: 69-75

26.Bachmann LH, Hobbs MM, Seña AC, Sobel JD, Schwebke JR, Krieger JN, et al. Trichomonas vaginalis genital infections: progress and challenges. Clin Infect Dis 2011; 53: S160-72.

27.Lally P, van Jaarsveld CH, Potts HW, Wardle J. How are habits formed: Modelling habit formation in the real world. Eur J Soc Psychol 2010; 40:9981009.

28.Manson PR, Super H, Fripp PJ. Comparison of four techniques for the routine diagnosis of Trichomonas vaginalis infection. J Clin Pathol 1976; 29: 154-7.

29.deLemos PA, Gracia-Zapata MT, Guimaraes NM, Moris RG. Comparison of methods for identification of Trichomonas vaginalis in HIV positive and negative women. Int $\mathbf{J}$ Trop Med 2009; 4:76-81.

\section{How to cite this article:}

Rachna Tewari, Motilal P. Sah and Mridu Dudeja. 2017. Prevalence of Candida and Trichomonas in Vaginal Discharge of Rural Females not Seeking Medical Help: Microscopy and Its Role in Vaginitis. Int.J.Curr.Microbiol.App.Sci. 6(10): 3023-3029. doi: https://doi.org/10.20546/ijcmas.2017.610.356 